\section{Shevchenko A., \\ Shevchenko T., \\ Pinchuk 0., \\ Kunytskyi 5., \\ Miasoiedov $\mathbf{0}$.}

\title{
LABORATORY STUDIES OF THE COAGULATION PROCESS OF WASTE WATERS OF MILK PROCESSING ENTERPRISES BY CHANGING THE MIXING RATE
}

\begin{abstract}
Наведено результати лабораторних досліджень з вивчення прочесу коагулящї забруднень y модельних стічних водах молокопереробних підприємств. Вивчено вплив зміни швидкості перемішування на ефективність процесу прояснення модельних стічних вод. Отримано залежності ефекту прояснення від швидкості перемішування.
\end{abstract}

Ключові слова: проба стічних вод, коагуляції забруднень, перемішуючий пристрій, швидкість та час перемішування, коефіцієнт світопоглинання.

\section{Introduction}

Mixing of liquid media is a process widely used in the food processing industry and other industries for the preparation of emulsions, suspensions and the production of homogeneous systems (solutions), as well as for the intensification of reaction, heat and diffusion processes [1]. Milk processing plants generate wastewater, which are characterized by an increased content of organic contaminants, fats, surfactants, etc. Therefore, the treatment of these wastewaters is very often carried out using coagulants [2, 3]

Treatment of water with coagulants is the most common method of purifying both natural and waste water. The hydrodynamic mixing regime (hydraulic, pneumatic and other methods) of the coagulant solution with water determines the kinetics of floccule formation, their size and density, and, thus, determines the subsequent stages of the purification technology.

To ensure the effective action of the coagulant, it must be immediately dispersed until a homogeneous distribution is obtained, which operation must be performed before sedimentation of the hydroxides [4].

The choice of hydrodynamic mode of the mixer is a complex technological task. This is due to the fact that the process of flocculation of hydrolyzed forms of coagulants (aluminum or iron hydroxides) is complex. The formation of floccules of coagulant hydroxides is determined by a large number of factors: the intensity of mixing, the turbidity of the initial water, the administered dose and type of coagulant, the temperature, etc. At the same time, it is known that the hydrodynamic regime created by mechanical mixers is more effective [5].

To mix the reagents, hydraulic mixers - swirl, vortex, gate, are most often used. Mixers with mechanical stirring were also widely used. The main positive difference between mechanical mixing and other methods of intensifying the coagulation process is the ability to regulate the mixing intensity depending on the quality, temperature and flow rate of the treated water. This allows to reduce the residence time of water in the mixer, which makes it possible to reduce its volume and, accordingly, to reduce the capital costs for the same water consumption.

The more effective the process of coagulation treatment of water, the better flocculation process takes place $[4,6]$. In case of incomplete mixing, there is a local lack of concentration of the reagent or vice versa local overdose, which leads to a poor quality of the purification process. Therefore, the definition of mixing parameters is one of the most important tasks.

The use of mineral coagulants in technological schemes for wastewater treatment of milk processing plants is a common technique. This makes it possible to intensify the process of physical and chemical wastewater treatment. However, the process of coagulation has a number of difficulties associated with the management and rapid mixing of coagulant with treated wastewater. Therefore, the studies given in this paper are aimed at studying the influence of the mixing rate of the coagulant with the waste fluid on the efficiency of the coagulation process.

\section{The object of research and its technological audit}

The object of research is the mixing process of the coagulant with the waste water of the milk processing industry by means of a stirrer at different speeds of rotation.

Mixers that are used for coagulation processing can be divided into two main types: propeller and static.

Propeller mixers are cylindrical (steel) or cubic configuration and equipped with a blade impeller, which can rotate at high speed.

Depending on the design of devices, the residence time in them varies from 1 to 3 minutes. The velocity gradient may be from 100 to $1000 \mathrm{~s}^{-1}$, depending on the particular application of the apparatus. The reagent enters the zone of greatest turbulence above or below the mixer, depending on the operating mode (suction or discharge). In those cases where the velocity gradient needs to be changed depending on the temperature or water contamination 
level that is being processed, the stirrer is equipped with a speed regulator.

Static mixers are installed directly on pipelines or open channels. Static mixers built into pipelines are characterized by very high velocity gradients (from 1000 to $30,000 \mathrm{~s}^{-1}$ ) and a short residence time of water in it [4].

The investigations carried out by the author [5] in the field of intensification of the coagulation water purification have shown that one of the methods for increasing the efficiency of water purification is providing optimal conditions for mixing reagents with water.

At the same time, the problem of determining the optimal mixing parameters for waste waters of milk processing enterprises remains open.

\section{The aim and objectives of research}

The aim of research is studying the effect of mixing intensity on the efficiency of wastewater treatment of milk processing plants during coagulation treatment.

To achieve this aim, it is necessary to solve the following main tasks:

1. To determine the effect of model wastewater solution mixing with the coagulant on the efficiency of the coagulation process.

2. To obtain graphical and mathematical dependencies of the change in the light absorption coefficient on the mixing intensity.

\section{Research of existing solutions of the problem}

A great contribution to the development of the mixing theory and practical solutions in the design of mixing devices is made by the authors of [7, 8]. According to [9], coagulants of aluminum sulphate, ferrous sulphate and chloride were the most widely used for treatment of wastewater from milk processing plants. At the same time, the efficiency of coagulant work was $53 \%$ for chemical oxygen demand (COD), for suspended substances - $93 \%$, for fats $-97 \%$, which is a rather effective indicator of preliminary wastewater treatment.

However, development of technology and the practical experience of mixing devices in various industries have revealed a number of problems in their work.

The authors of [10] establish that the process of flocculation as a result of water treatment with coagulants depends not only on the intensity of mixing (velocity gradient), but also on the temperature of the fluid being treated and the initial turbidity.

Rapid mixing after dosing of the coagulant is an important design parameter according to the data of [11]. The coagulant should be evenly mixed with water. In the case of incomplete mixing, local insufficient concentration of the reagent occurs or, conversely, a local overdose, which leads to a poor quality of the purification process. Therefore, the search for an optimal mixing device is one of the most important tasks.

One of the solutions for fast and complete mixing of reagents with wastewater is the mixer design presented in [12]. Studies on the work of this equipment indicate the achievement of a velocity gradient of $300 \mathrm{~s}^{-1}$ for a time of 10 to $60 \mathrm{~s}$. This allows a quick and high-quality mixing of the effluents and reagent solutions.
In [13], the authors analyze the classical theory of calculating the useful power of a stirrer and identified shortcomings in the calculations. To take into account these shortcomings, the authors propose to apply the finite element method in its modern application - computational hydrodynamics. Computational fluid dynamics in solving the problem allows to take into account the geometry of the problem to the maximum extent, and, thus, does not impose restrictions on the design scheme related to the need to simplify the mixer design or internal devices of the apparatus.

The paper [14] is devoted to the problem of the hydrodynamic effect of steady circulation in the vertical plane of a liquid placed in a cylinder rotating around a vertical axis. As experiments have shown, with an increase in the rotation speed of the liquid greater than a certain critical value, stable steady circulation appears in the vertical plane. This can cause an effective rise in the bottom layers of water, i. e., effective mixing of water masses with simultaneous saturation (aeration) of their air (oxygen).

To intensify the process of mixing water with reagents, the authors [15] propose a mixer design with an inclined impeller. According to the experimental studies, in the laminar flow region, the inclined impeller can reduce the mixing time compared to a stirrer with a vertically disposed impeller.

The authors of [16] propose a differential mixer design for increasing the efficiency of mixing aqueous solutions. Parametric studies are carried out and the optimization of the shape of the said mixer design is performed on their basis. When comparing two designs of mixers (standard and differential), the authors identify shortcomings of the standard mixer at high speeds (over 150), namely: a vortex is formed in the center of the liquid, which causes deformation of the mixer, bubbles and cavitation.

\section{Methods of research}

Laboratory studies were conducted on model sewage, representing aqueous solutions of dairy products with the addition of detergents (alkali or acid). The concentration of dairy products in such solutions was selected in such way that it corresponds to the content of fat and protein in the actual drains of milk processing plants.

The following instruments and materials were used for carrying out experimental studies:

1. Sample of sewage -5 liters (model wastewater).

2. Coagulant $-3 \%$ solution of ferric chloride $\mathrm{FeCl}_{3}$.

3. Stirring devices (electromagnetic stirrer MS-H280-Pro manufactured by ChemLand, Poland).

4. Device for determining the comparative characteristics of water turbidity (spectrophotometer DR 1900 produced by Hach LANGE, USA).

The order of the research: the total sample of model sewage was divided into several portions of $150 \mathrm{ml}$ each ( 2 series of experiments in 5 portions). In each serving, the initial temperature and $\mathrm{pH}$ were determined. Then, by the trial coagulation method, the required dose of the coagulant and the $\mathrm{pH}$ neutralization dose at a speed of $200 \mathrm{rpm}$ and a stirring time of $1 \mathrm{~min}$ were determined.

After processing a portion of the model runoff with reagents and stirring with a magnetic stirrer, the light absorption coefficient was determined on a spectrophotometer after 60 minutes for sedimentation. Based on the obtained results, the light absorption coefficient was plotted against the mixing rate. 


\section{Research results}

Mixing of the reagent solution with the model solution was carried out with the aid of a stirring device an electromagnetic stirrer. The necessary volume of wastewater in the stirring tank was placed on a stirrer, a predetermined stirring regime was set and the coagulant was dosed. During the mixing process, a certain value of the rotational speed of the mixer (100-1500 rpm) was established for each sample run. After the set mixing time (1 minute) has elapsed, the agitator was turned off, the wastewater was poured into the settling column. To carry out a comparative analysis of the turbidity of water after settling, a special device, a spectrophotometer, was used. According to the data obtained using the spectrophotometer, the curve of the dependence of the light absorption coefficient on the rotation speed of the mixer was constructed. The experiments were carried out at different rotational speeds.

The choice of the best mixing regime for reagents and flocculation was carried out by comparing the experimental data obtained for the light absorption coefficient of the processed model runoff for the investigated mixing regimes.

Coagulation quality evaluation was carried out by measuring the purity of the filtrate (by the value of the light absorption coefficient). Measurements of the light absorption coefficient using a spectrophotometer were carried out at a wavelength of $800 \mathrm{~nm}$ and $480 \mathrm{~nm}$.

A model sample of wastewater was obtained by dissolving milk-containing products in water. The composition and percentage of the model sample of sewage are given in Table 1. The total volume of each model sample of obtained sewage was 5 liters.

Table 1

Composition and percentage ratio of model sewage sample

\begin{tabular}{|c|c|c|c|}
\hline \multicolumn{2}{|c|}{ Mass fraction, \% } & \multirow{2}{*}{ Product } & \multirow{2}{*}{ Fat content, \% } \\
\cline { 1 - 2 } Sample No. 1 & Sample No. 2 & & \\
\hline 5.0 & 1.5 & milk & 3.2 \\
\hline 3.0 & 1.0 & spoiled milk & 3.0 \\
\hline 1.0 & 0.5 & sour cream & 18 \\
\hline 92.0 & 97.0 & water & 0 \\
\hline
\end{tabular}

After mixing all the products, the sample was aged for 30 minutes. Then the general model sample was divided into several portions of $150 \mathrm{ml}$ each (Fig. 1). Each portion of the model wastewater was treated with reagent solutions. In model wastewater of sample No. 1, $5 \mathrm{ml}$ of a $5 \%$ solution of alkali $\mathrm{NaOH}$ was added to neutralize the $\mathrm{pH}$ and $1.8 \mathrm{ml}$ of a $3 \%$ solution of ferric chloride $\mathrm{FeCl}_{3}$ for coagulation. For a sample of model sewage No. 2, $1.2 \mathrm{ml}$ of a $5 \%$ solution of alkali $\mathrm{NaOH}$ was added to neutralize the $\mathrm{pH}$ and $1.8 \mathrm{ml}$ of a $3 \%$ solution of ferric chloride $\mathrm{FeCl}_{3}$ for coagulation.

The dose of the coagulant is the selected dose obtained during the trial coagulation. Despite the fact that when changing the composition of model wastewater the optimal dose of coagulant could change, it was decided to leave the same dose of coagulant according to the composition of the sample with $\mathrm{pH}$ neutralization. This was done to observe the established experimental parameters and the possibility of their further comparison among themselves.

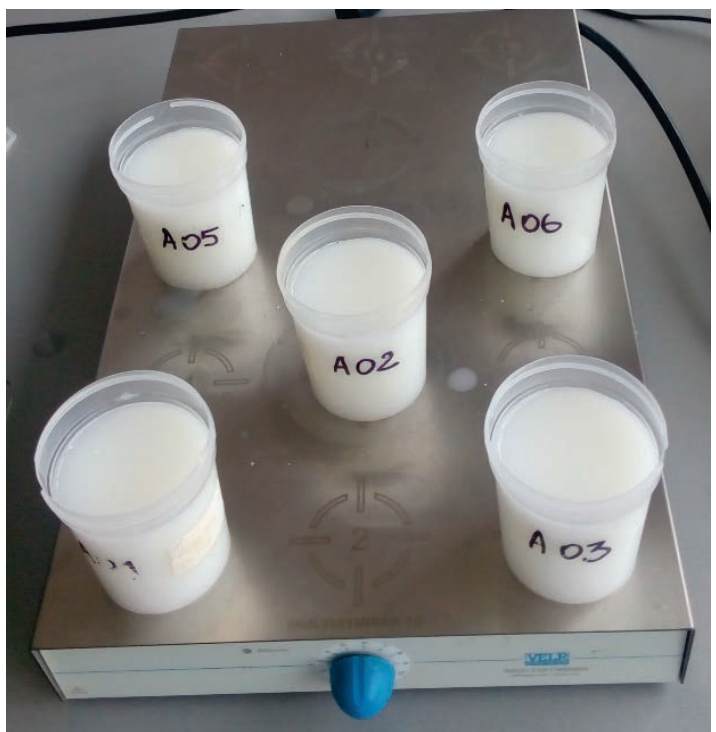

Fig. 1. Portions of model wastewater prior to coagulant administration

Before mixing on a magnetic stirrer, the portion of the model runoff had the following qualitative parameters:

- $\mathrm{pH}=7$ (neutral medium is provided by the intro-

duction of alkali);

- model flow temperature is $19{ }^{\circ} \mathrm{C}$.

The reagents were added to portions of the model wastewater while stirring on a magnetic stirrer (Fig. 2). Mixing time is $1 \mathrm{~min}$. The shape of the anchor of the magnetic stirrer is cylindrical, the dimensions of the anchor are $40 \times 8 \mathrm{~mm}$, the diameter of the container is $70 \mathrm{~mm}$, the height of the container is $45 \mathrm{~mm}$.

During the experiment, the mixing rate varied within the following limits:

- 1 series (model test No. 1) - 300-1100 rpm;

- 2 series (model test No. 2) - 100-1500 rpm.

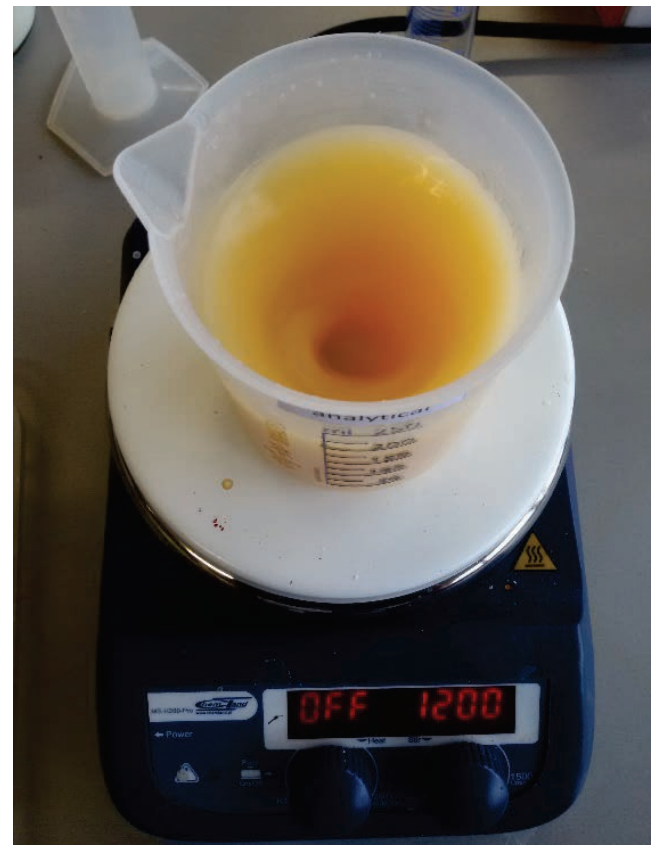

Fig. 2. Stirring of model sewage with a coagulan on a magnetic stirrer 
The processed samples were left for $60 \mathrm{~min}$ for sedimentation. After that each of them was filtered on a coarse filter (Fig. 3). Further, on the spectrophotometer, the light absorption coefficients were determined at wavelengths $\lambda=800 \mathrm{~nm}$ and $\lambda=480 \mathrm{~nm}$. The results are shown in Table 2 .

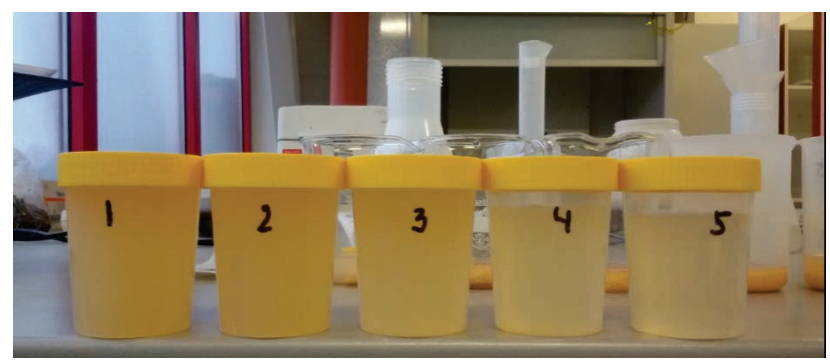

Fig. 3. Model sewage of sample No. 2 after filtering on a coarse filter

According to Table 2, the mathematical and graphical dependences of the light absorption coefficient on the mixing rate during model waste water coagulation are obtained (Fig. 4, 5), which correspond to an exponential function with a high degree of correlation $\left(R^{2}=0.98\right)$.

To compare the obtained results of the light absorption coefficient at different wavelengths of the spectrophotometer, $\lambda=800 \mathrm{~nm}$ and $\lambda=480 \mathrm{~nm}$, the graphical and mathematical relationships between the light absorption coefficient and the turbidity are obtained (Fig. 6).

As a result of studying the obtained graphs (Fig. 4-6), it is found that the change in the mixing rate of the model wastewater solution with the coagulant with iron chloride significantly affects the coagulation process. The quality of the coagulation process is evaluated by measuring the purity of the obtained filtrate from the value of the light absorption coefficient on the spectrophotometer.

The results show an exponential dependence of the quality of the coagulation process on the mixing rate with a high correlation coefficient $\left(R^{2}=0.98\right)$. The nature of the obtained curves indicates that in the range of rotational speeds of the mixer 100-800 rpm the coefficient of light absorption decreases from 1.544 to 0.314 , which is $79.7 \%$. At the mixer rotation speed in the range of 800-1500 rpm, the coagulation efficiency practically does not change and reaches the maximum value for the coefficient of light absorption 0.168 , which is $89.1 \%$. Therefore, it is pos- sible to conclude that the range of rotational speeds of the stirrer $800-1500 \mathrm{rpm}$ is optimal for achieving the maximum effect of the coagulation process in the treatment of wastewater from milk processing plants.

The decrease in the value of the light absorption coefficient is significant, therefore, the mixing factor is significant in the process of coagulation of sewage of milk processing plants. According to the research results, there is a need to improve the quality of agitation of the coagulant with wastewater. The latter will improve the quality of wastewater treatment of milk processing enterprises.

Table 2

The values of the light absorption coefficient in the mixer, depending on the mixing speed

\begin{tabular}{|c|c|c|c|}
\hline No. & $\begin{array}{c}\text { Number of revo- } \\
\text { lutions, } n, \text { гpm }\end{array}$ & $\begin{array}{c}\text { The wavelength } \\
\text { of the spectrophotometer, } \\
\lambda, \mathrm{nm}\end{array}$ & $\begin{array}{c}\text { Light absorption } \\
\text { coefficient, } A \text {, abs. }\end{array}$ \\
\hline 1 & \multicolumn{3}{|c|}{ Model wastewater sample No. 1} \\
\hline 1.1 & 300 & 800 & 0.728 \\
\hline 1.2 & 500 & 800 & 0.447 \\
\hline 1.3 & 700 & 800 & 0.194 \\
\hline 1.4 & 900 & 800 & 0.151 \\
\hline 1.5 & 1100 & 800 & 0.065 \\
\hline 2 & \multicolumn{3}{|c|}{ Model wastewater sample No. 2} \\
\hline 2.1 & 100 & 800 & 1.544 \\
\hline 2.2 & 200 & 800 & 1.124 \\
\hline 2.3 & 400 & 800 & 0.647 \\
\hline 2.4 & 800 & 800 & 0.314 \\
\hline 2.5 & 1500 & 800 & 0.168 \\
\hline 3 & \multicolumn{3}{|c|}{ Model wastewater sample No. 3} \\
\hline 3.1 & 100 & 480 & 2.894 \\
\hline 3.2 & 200 & 480 & 2.468 \\
\hline 3.3 & 400 & 480 & 1.765 \\
\hline 3.4 & 800 & 480 & 0.932 \\
\hline 3.5 & 1500 & 480 & 0.598 \\
\hline
\end{tabular}

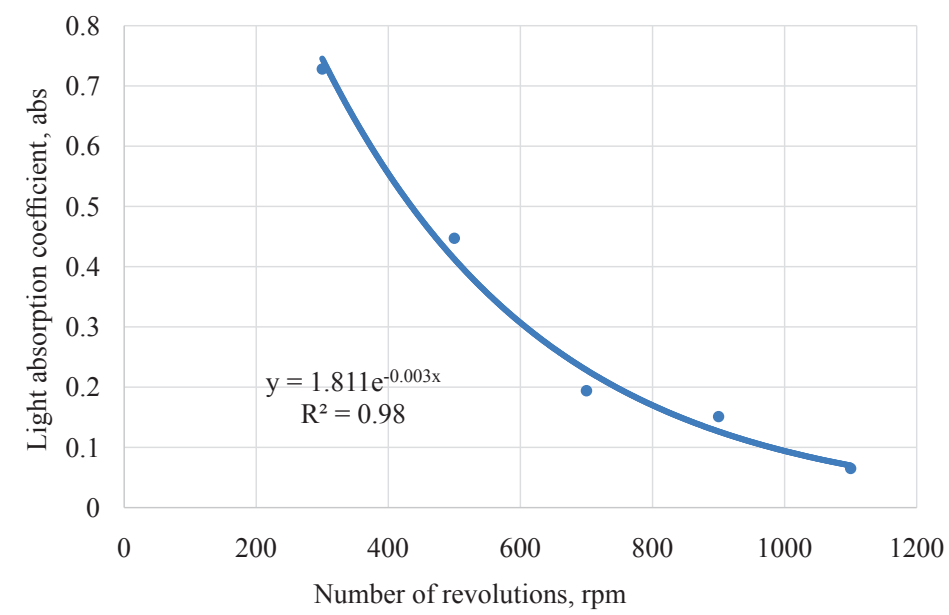

Fig. 4. Dependence of the light absorption coefficienton the mixing rate during coagulation of the model solution (sample No. 11) 


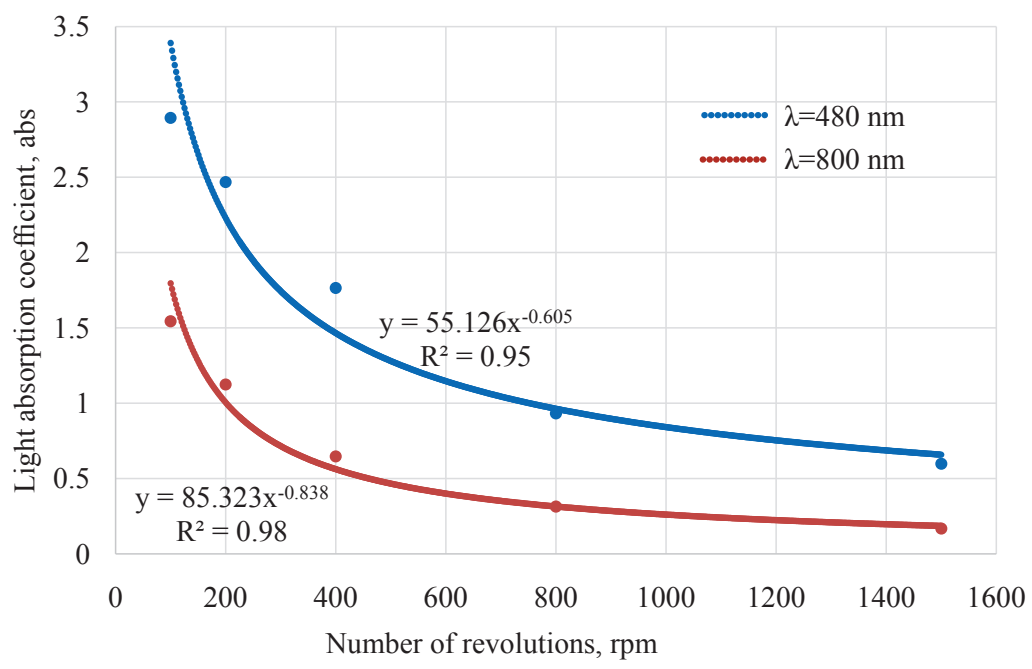

Fig. 5. Dependence of the light absorption coefficient on the mixing rate of sample No. 2 at a wavelength $\lambda=800 \mathrm{~nm}$ and $\lambda=480 \mathrm{~nm}$

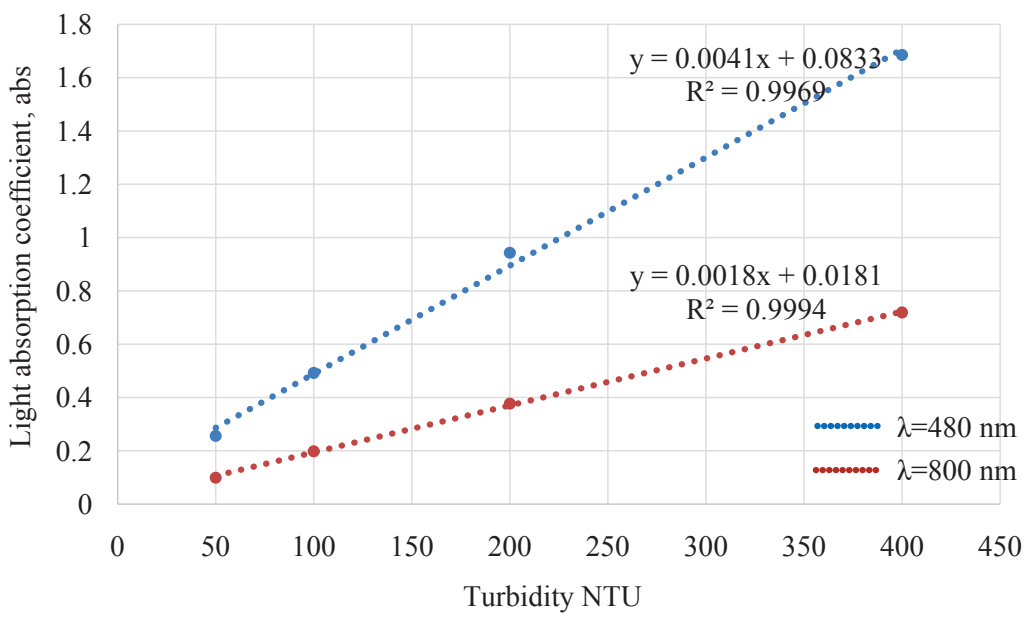

Fig. 6. Dependence of turbidity on the light absorption coefficient for measurements at different wavelengths of the spectrophotometer

\section{SWOT analysis of research results}

Strengths. The carried out researches have shown expediency of definition of mixing modes of coagulant with processed waste water for maintenance of optimum mixing parameters in mixing devices. This will allow for more complete use of the coagulant capacity of the reagents, complete and rapid mixing with the waste liquid. This will ultimately lead to cost savings for reagents and to optimize the operation of the whole technological scheme for wastewater treatment of milk processing enterprises.

Weaknesses. The introduction of an effective knot of mixing the coagulant with the waste fluid leads to additional labor costs. This unit requires qualified maintenance and monitoring of the hydrodynamic parameters of the mixing flows of liquids.

Opportunities. The qualitative, rapid and complete mixing of the coagulant with the waste liquid will make it possible to intensify the process of physical and chemical treatment of waste waters of milk processing enterprises. This, in turn, will entail a normal course of further purification steps.
Threats. The effectiveness of the process of mixing wastewater and coagulant is influenced by the qualitative parameters of the effluent (contamination concentration, $\mathrm{pH}$, temperature, etc.) and the parameters of the mixing device. Therefore, a sharp change in the qualitative and quantitative parameters of the effluent can lead to a disturbance of the mixing process and affects the overall purification efficiency.

\section{Conclusions}

1. As a result of carrying out experimental studies on the effect of the mixing speed of model sewage solution with the ferric chloride coagulant, it is found that the mixing regime has a significant effect on the efficiency of the coagulation process. Thus, at an impeller speed of $1500 \mathrm{rpm}$, the purification efficiency reached $89.1 \%$.

2. Based on the results of the experiments, graphical and mathematical dependences of the change in the light absorption coefficient on the intensity of mixing with a high degree of correlation are obtained $\left(R^{2}=0.98\right)$. The nature of the obtained curves indicates that in the range of rotational speeds of the mixer $100-800 \mathrm{rpm}$, the 
purification efficiency was $79.7 \%$. At a speed of stirrer rotation in the range $800-1500 \mathrm{rpm}$, the coagulation efficiency practically does not change and reaches a maximum value of $89.1 \%$. The decrease in the value of the light absorption coefficient is significant, therefore, the mixing factor is significant in the process of sewage coagulation of milk processing plants.

The results of the conducted studies confirm the expediency of determining the mixing regimes of the coagulant with processed sewage to ensure optimal mixing parameters in the mixing devices. The mixing intensity has a significant effect on the coagulation efficiency and, as a consequence, the efficiency of wastewater treatment.

\section{References}

1. Ivanets V. N., Lobasenko B. A. Metody intensifikatsii gidromehanicheskih protsessov: handbook. Kemerovo: Kemerovo Institute of Food Science and Technology, 2003. 84 p.

2. Shevchenko T., Shevchenko A. Intensifikatsiia raboty flotatsionnoi ustanovki pri ochistke stochnyh vod predpriiatii molochnoi promyshlennosti // Visnyk Odeskoi derzhavnoi akademii budivnytstva ta arkhitektury. 2015. Vol. 59. P. 151-156.

3. Shevchenko A., Shevchenko T. Computer simulation of hydraulic flow in a mixing device with a diaphragm of special design installed in it // Eastern-European Journal of Enterprise Technologies. 2017. Vol. 3, No. 7 (87). P. 33-39. doi:10.15587/1729-4061.2017.100835

4. DEGREMONT. Tehnicheskii spravochnik po obrabotke vody: translation from French. Saint Petersburg: Novyi zhurnal, 2007. Vol. 1. 878 p.

5. Moiseev A. V. Intensifikatsiia protsessov koaguliatsii i flokuliatsii prirodnyh vod za schet reguliruemogo mehanicheskogo peremeshivaniia v smesiteliah i kamerah hlop'eobrazovaniia ochistnyh sooruzhenii: abstract's PhD thesis: 05.17.08. Moscow, 2005. $23 \mathrm{p}$.

6. Alekseeva L. P. Intensifikatsiia provedeniia protsessa koaguliatsionnoi ochistki vody // Nailuchshie Dostupnye Tehnologii vodosnabzheniia i vodootvedeniia. 2014. Vol. 3. P. 6-13.

7. Romankov P. G., Frolov V. F., Flisiuk O. M. Metody rascheta protsessov i apparatov himicheskoi tehnologii (primery i zadachi): handbook. Saint Petersburg: HIMIZDAT, 2009. 544 p.

8. Mihir Sh. Process Engineering: Agitation \& Mixing. Nadiad, Gujarat: Anchor Institute Dharamsinh Desai University, 2014. $164 \mathrm{p}$.

9. Epoian S. M., Fomin S. S., Shilin V. V. Otsenka effektivnosti raboty koaguliantov pri ochistke proizvodstvennyh stochnyh vod molokopererabatyvaiushchih predpriiatii // Naukovyi visnyk budivnytstva. 2016. Vol. 3. P. 151-154.

10. WATER TREATMENT. Coagulation and flocculation. URL: https://ocw.tudelft.nl/wp-content/uploads/Coagulation-andflocculation-1.pdf (Last accessed: 04.11.2017).

11. Mordanov S. V., Syromiatnikov S. N., Homiakov A. P. Metodika rascheta poleznoi moshchnosti mehanicheskogo peremeshivaiushchego ustroistva // Trudy nauchnoi konferentsii «Dostizheniia v himii i himicheskoi tehnologii». Ekaterinburg, 2011. P. 9-14.
12. Coagulation and Flocculation in Water and Wastewater Treatment. URL: https://www.iwapublishing.com/news/coagulationand-flocculation-water-and-wastewater-treatment (Last accessed: 17.12.2017).

13. Rasha A. J. Effect of Temperature on Floc Formation Process Efficiency and Subsequent Removal in Sedimentation Process // Journal of Engineering and Development. 2014. Vol. 18, No. 4. P. 176-187.

14. Rykov S. V., Mamina D. H. Gidrodinamicheskii effekt i vozmozhnosti ego prakticheskogo primeneniia // Internet-zhurnal «Naukovedenie». 2013. Vol. 6. URL: https://naukovedenie. ru/PDF/148TVN613.pdf (Last accessed: 04.11.2017).

15. Laminar Mixing in Stirred Tank Agitated by an Impeller Inclined / Takahashi K. et al. // International Journal of Chemical Engineering. 2012. Vol. 2012. P. 1-10. doi:10.1155/2012/858329

16. Asiri S. Design and Implementation of Differential Agitators to Maximize Agitating Performance // International Journal of Mechanics and Applications. 2012. Vol. 2, No. 6. P. 98-112. doi:10.5923/j.mechanics.20120206.01

\section{ЛАБОРАТОРНЫЕ ИССЛЕДОВАНИЯ ИНТЕНСИФИКАЦИИ ПРОЦЕССА КОАГУЛЯЦИИ СТОЧНЫХ ВОД МОЛОКОЛЕРЕРАБАТЫВАЮЩИХ ПРЕДПРИЯТИЙ ЗА СЧЕТ ИЗМЕНЕНИЯ СКОРОСТИ} ПЕРЕМЕШИВАНИЯ

Приведены результаты лабораторных исследований по изучению процесса коагуляции загрязнений в модельных сточных водах молокоперерабатывающих предприятий. Изучено влияние изменения скорости перемешивания на эффективность процесса осветления модельных сточных вод. Получены зависимости эффекта осветления от скорости перемешивания.

ключевые слова: проба сточных вод, коагуляция загрязнений, перемешивающее устройство, скорость и время перемешивания, коэффициент светопоглощения.

Shevchenko Andrii, Engineer of Environmental Engineering, PRODEKO-ELK Sp. z o.o., Elk, Poland, ORCID: http://orcid.org/ 0000-0002-7332-5661, e-mail: shevchenko950@gmail.com

Shevchenko Tamara, PhD, Associate Professor, Department of Water Supply, Sanitation and Clean Water, O. M. Beketov National University of Urban Economy in Kharkiv, Ukraine, e-mail: Tamara.Shevchenko@kname.edu.ua, ORCID: http://orcid.org/00000002-4513-6759

Pinchuk Oleg, PhD, Department of Hydroinformatics, National University of Water and Environmental Engineering, Rivne, Ukraine, e-mail: o.l.pinchuk@nuтт.edu.ua, ORCID: http://orcid.org/00000001-6566-0008

Kunytskyi Sergiy, PhD, Research Department, National University of Water and Environmental Engineering, Rivne, Ukraine, e-mail: s.o.kunytskiy@nuтьm.edu.ua, ORCID: http://orcid.org/0000-00030318-6149

Miasoiedov Oleksii, Chemical Engineer, PRODEKO-ELK Sp. z o.o., Elk, Poland, e-mail:miaso.keo@gmail.com, ORCID: https://orcid.org/ 0000-0001-6630-0952 